\title{
Nitric Oxide Synthesis Inhibition and Anti-Inflammatory Effect of Polypeptide Isolated from Chicken Feather Meal in Lipopolysaccharide-Stimulated RAW 264.7 Macrophages
}

\section{Aurachorn Inkanuwat ${ }^{1} \oplus$ Romteera Sukaboon²®, Onrapak Reamtong ${ }^{3}$, Pravit Asawanonda ${ }^{4} \odot$, Ake Pattaratanakun ${ }^{5}{ }^{\circ}$, Tanatorn Saisavoey ${ }^{6}$, Papassara Sangtanoo ${ }^{6} \odot$ and Aphichart \\ Karnchanatat ${ }^{6 *}$ (1)}

${ }^{1}$ Technopreneurship and Innovation Management Program, Graduate School, Chulalongkorn University, 254 Phayathai Road, Pathumwan, Bangkok 10330, Thailand

${ }^{2}$ Program in Biotechnology, Faculty of Science, Chulalongkorn University, 254 Phayathai Road, Pathumwan, Bangkok 10330, Thailand

${ }^{3}$ Department of Molecular Tropical Medicine and Genetics, Faculty of Tropical Medicine, Mahidol University, 420/6 Ratchawithi Road, Ratchathewi, Bangkok 10400, Thailand

${ }^{4}$ Department of Medicine, Faculty of Medicine, Chulalongkorn University, 254 Phayathai Road, Pathumwan, Bangkok 10330, Thailand

${ }^{5}$ Department of Marketing, Faculty of Commerce and Accountancy, Chulalongkorn University, 254 Phayathai Road, Pathumwan, Bangkok 10330, Thailand

${ }^{6}$ Research Unit in Bioconversion/ Bioseparation for Value-Added Chemical Production, Institute of Biotechnology and Genetic Engineering, Chulalongkorn University, 254 Phayathai Road, Pathumwan, Bangkok 10330, Thailand

Received: 2 August 2018 Accepted: 26 March 2019

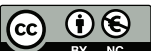

*Corresponding author:

Phone: +6622188078

Fax: +6622188069

E-mail: Aphichart.K@chula.ac.th

\begin{abstract}
SUMMARY
Nitric oxide (NO) plays a key role in the pathogenesis of inflammation and has been implicated in endotoxin-induced tissue injury. Chicken feather meal is a rich source of amino acids that may serve as a peptide hydrolysate to inhibit NO activity. Anti-inflammatory hydrolysates of chicken feather meal were prepared and fractionated into five samples based on molecular mass. The smallest fraction $(<0.65 \mathrm{kDa})$ exhibited the highest NO inhibitory activity without cytotoxicity towards macrophage RAW 264.7 cells. Further subfractions were sufficient to obtain amino acid sequences by Q-TOF LC-MS/MS ESI analysis. Of these, the SNPSVAGVR (885.97 Da) peptide and its corresponding pure synthetic peptide have inhibitory activity against NO production by RAW 264.7 cells $\left(I C_{50}=(55.2 \pm 0.2) \mathrm{mM}\right)$ without cytotoxicity. Reverse transcriptase polymerase chain reaction (RT-PCR) and quantitative real-time RT-PCR results revealed that the peptide of the obtained fraction reduced transcript expression levels of the pro-inflammatory cytokines iNOS, TNF- $a$, COX-2 and IL-6 in lipopolysaccharide-stimulated RAW 264.7 cells. These results suggest that the peptides derived from the chicken feather meal protein could potentially be used as a promising ingredient in functional foods or nutraceuticals against inflammatory diseases.
\end{abstract}

Key words: nitric oxide, anti-inflammatory activity, chicken feather meal, protein hydrolysate, polypeptide, macrophage RAW 264.7

\section{INTRODUCTION}

Inflammation is a host defence mechanism that involves physiological and pathological processes within an organism, and is induced by the invasion of pathogens or tissue injury caused by biological, chemical or physical damage (1). The activation of several immune cells (monocytes and macrophages) produces inflammation mediators, such as nitric oxide (NO), cyclooxygenase-2 (COX-2), prostaglandins E2 (PGE2) and other pro-inflammatory cytokines (iNOS), including tumour necrosis factor alpha (TNF-a), interleukin-6 (IL-6) and interleukin-1 $\beta$ (2). Macrophages play an important role in inflammation and this cellular response is initiated by bacterial lipopolysaccharide (LPS), which is part of the outer membrane of Gram-negative bacteria, interferon- $\gamma$ (IFN- - ) and pro-inflammatory cytokines (3). Oxidative stress is involved in the pathogenesis of several diseases. Physical and biochemical processes in the human body generate free radicals as byproducts that trigger a wide range of diseases (4). The interaction of reactive nitrogen species and reactive oxygen species (ROS), e.g. NO, with toxic agents is strongly linked with inflammation, while the uncontrolled production of these species is linked to several diseases, including cancer, coronary heart disease, rheumatoid arthritis, asthma and Alzheimer's (5). During inflammatory processes, inflammatory mediators, such as NO and PGE2, are produced via the oxidation of L-arginine by inducible nitric oxide synthase (iNOS) and the conversion of arachidonic acid by COX-2. Moreover, NO is a key signalling biological molecule involved in vasodilation, regulation of blood pressure, neurotransmission and the host immune defence system. Inflammation can be regulated by suppression of the pro-inflammatory cytokines and NO production (6). 
Currently, there is an increasing interest in food proteins and their constituent peptides as potential candidates for use as antioxidant and anti-inflammatory agents (7). The production and development of functional food or dietary supplements has increased significantly and these products have been used to aid human health (8). Peptides are highly selective, efficient and completely safe for humans (9). These peptides are often functionally inactive within native proteins and must be released by hydrolysis using enzymes such as Alcalase, Flavourzyme and Neutrase to achieve their specific bioactive roles (10). Recently, significant pharmaceutical research has been undertaken in an effort to use bioactive peptides from plants or animals as potential medicines and to underpin research into drug development (11). Currently, bioactive peptides that display anticancer (12), antimicrobial (13), hypocholesterolemic (14), antihypertensive (15), and anti-inflammatory properties (16) have been identified.

Poultry processing plants and related industries are expanding in many countries, especially in Thailand. Although chicken feather meal represents around 5-7\% of the body mass of chicken, it is a major waste byproduct of poultry processing, with large amounts produced annually, and its substantial accumulation causes potential environmental problems and pollution. Instead, chicken feather meal can be used as an alternative value-added product as animal feed or feed supplement and organic fertilizer due to its high (80-90\%) protein content, as well as being rich in hydrophobic amino acids (17). The objective of this study is to prepare peptides from chicken feather meal by enzymatic hydrolysis using microbial proteases and then to determine the in vitro anti-inflammatory effect of the isolated peptide samples on macrophage RAW 264.7 cells. The results indicate that chicken feather meal is a suitable source of anti-inflammatory peptides, which can be further developed in the pharmaceutical industry or as an ingredient in cosmetic products on the global market.

\section{MATERIALS AND METHODS}

\section{Biological materials}

The chicken feather meal used in this study was obtained from Betagro Science Center Co., Ltd. (Pathumthani, Thailand) and was ground to small particles and dried at $60{ }^{\circ} \mathrm{C}$ overnight. Then it was filtered through a $150-\mu \mathrm{m}$ sieve to give a more homogenous particle size distribution for better accuracy and consistency of the results.

\section{Chemicals}

Alcalase and Flavourzyme were purchased from Brentag (Mülheim, Germany). Neutrase was purchased from Novozymes (Bagsværd, Denmark). Acetic acid, ethanol and phosphoric acid were purchased from Merck (Gibbstown, NJ, USA). Acetonitrile (ACN), L-a-amino-n-butyric acid, bovine serum albumin (BSA), budesonide, curcumin from Curcuma longa (turmeric), Coomassie brilliant blue G-250,
3-(4,5-dimethylthiazol-2-yl)-2,5-diphenyl-2H-tetrazolium bromide (MTT), dimethyl sulfoxide (DMSO), disodium hydrogen phosphate, Dulbecco's modified Eagle medium (DMEM), foetal bovine serum (FBS), phosphoric acid, formic acid, hydrochloric acid, 4-(2-hydroxyethyl)-1-piperazineethanesulfonic acid (HEPES), methanol, monosodium dihydrogen orthophosphate, mouse interferon gamma (IFN- $\gamma$ ), lipopolysaccharides (LPS) from Escherichia coli, potassium persulfate, sodium nitrite, (1-naphthyl)ethylenediamine (NED), sodium nitroprusside (SNP), sodium pyruvate, streptomycin sulphate, sulphanilamide, and trifluoroacetic acid (TFA) were purchased from Sigma-Aldrich, Merck (St. Louis, MO, USA).

\section{Determination of the chicken feather meal amino acid content}

The amino acid content of the chicken feather meal was determined based on the standard AOAC method 994.12 (18). One gram of chicken feather meal was dissolved in $5 \mathrm{~mL}$ of 6 $\mathrm{M} \mathrm{HCl}$ in a test tube and then placed into a heating block at $110^{\circ} \mathrm{C}$ for $24 \mathrm{~h}$ to liberate the amino acids. The internal standard (10 mL $2.5 \mathrm{mM} \mathrm{L-a-amino-} n$-butyric acid in $0.1 \mathrm{M} \mathrm{HCl}$ ) was added to this sample, diluted with deionized water to $250 \mathrm{~mL}$ and placed in a heating block at $55^{\circ} \mathrm{C}$ for $10 \mathrm{~min}$. Amino acids were analysed by reversed-phase high performance liquid chromatography (RP-HPLC; Waters Corporation, Milford, MA, USA) using a Hypersil GOLD column $\mathrm{C}_{18}(50 \mathrm{~mm} \times 0.5 \mathrm{~mm}$, $5 \mu \mathrm{m}$; Thermo Fisher Scientific, San Jose, CA, USA) shielded by a guard column on a Hypersil GOLD $(30 \mathrm{~mm} \times 0.5 \mathrm{~mm}, 5 \mu \mathrm{m}$ $\mathrm{C}_{18}$; Thermo Fisher Scientific, San Jose, CA, USA, elution buffer of $20 \mathrm{mM}$ sodium acetate $(\mathrm{pH}=4.90)$ and $60 \%$ acetonitrile $(A C N)$ at a flow rate of $0.3 \mathrm{~mL} / \mathrm{min}$.

\section{Preparation of enzymatic hydrolysate from chicken feather meal}

The sieved chicken feather meal $(5 \mu \mathrm{g})$ was mixed with $100 \mathrm{~mL}$ of phosphate-buffered saline (PBS; $20 \mathrm{mM}$ phosphate buffer, $0.15 \mathrm{M} \mathrm{NaCl}, \mathrm{pH}=7.2$ ) and stirred at $4^{\circ} \mathrm{C}$ overnight. The suspension was then hydrolysed with one of three types of microbial proteases (Alcalase, Flavourzyme (both from Brentag) and Neutrase (Novozymes)) at 0, 1, 2.5 or $5 \%(\mathrm{~m} / \mathrm{V})$ for $4 \mathrm{~h}$ at $50^{\circ} \mathrm{C}$ and $\mathrm{pH}=7$ (except for Alcalase treatment which was at $\mathrm{pH}=8$ ) with shaking (180 rpm; model Innova 4330 refrigerated floor incubator shaker; New Brunswick Scientific (UK) Ltd., Hatfield, Herts, UK). After hydrolysis, the mixtures were heated to $90^{\circ} \mathrm{C}$ for $10 \mathrm{~min}$ to inactivate the enzymes and the samples were clarified by centrifugation (model Kubota 6500; Shimadzu, Kyoto, Japan) at $6440 \times g$ for $15 \mathrm{~min}$. The supernatant (i.e. hydrolysate) was collected and stored at $-20^{\circ} \mathrm{C}$ until use.

\section{Protein content determination}

The concentration of the chicken feather meal protein hydrolysate was determined according to the Bradford procedure (19), using BSA as the standard protein to construct the 
calibration curve. For each sample three aliquots $(20 \mu \mathrm{L})$ were separately mixed with $200 \mu \mathrm{L}$ of the Bradford working solution (50 mg of Coomassie brilliant blue G-250 in $50 \mathrm{~mL}$ of methanol and $100 \mathrm{~mL} 85 \%(\mathrm{~m} / \mathrm{V}$ ) phosphoric acid) in a 96-well plate (flat-bottom 96-well; Bio-Rad Laboratories, Inc., Hercules, MA, USA), incubated for $20 \mathrm{~min}$ and then the absorbance was measured at $A_{540 \mathrm{~nm}}$ with a microplate reader (Multiskan GO; Thermo Fisher Scientific, Waltham, MA, USA). The protein content in each sample was determined from the standard curve derived from the BSA measurements.

\section{NO radical scavenging assay}

The NO radical scavenging assay was slightly modified from that previously reported by Chantaranothai et al. (20). The peptide hydrolysates $(5 \mu \mathrm{L})$ were mixed with $10 \mathrm{mM}$ of SNP in PBS and incubated at room temperature for $150 \mathrm{~min}$ before the addition of $100 \mu \mathrm{L}$ of Griess reagent $(0.33 \%$ sulfanilamide in $5 \%$ phosphoric acid) and incubation for 5 min. Next, $100 \mu \mathrm{L}$ NED were added and the samples were incubated for $30 \mathrm{~min}$ at room temperature before measurement of the absorbance at $540 \mathrm{~nm}$ using a microplate reader (model Multiskan GO, Thermo Fisher Scientific Inc., San Jose, CA, USA). The percentage of NO inhibition (\%) and concentration of hydrolysate that inhibited $50 \%$ of the NO radical production $\left(\mathrm{IC}_{50}\right)$ were calculated, the latter using the GraphPad Prism v. 6.01 for Windows (GraphPad Software Inc., San Diego, CA, USA) (21). Curcumin was used as the positive control. The NO scavenging activity (\%) was calculated from:

$$
\text { NO inhibition }=\frac{\left(A_{\text {control }}-A_{\text {blank }}\right)-\left(A_{\text {sample }}-A_{\text {background }}\right)}{\left(A_{\text {control }}-A_{\text {blank }}\right)} \cdot 100 \quad / 1 /
$$

where $A_{\text {control }}$ is the absorbance of the control (no sample), $A_{\text {sample }}$ is the absorbance of the sample, $A_{\text {background }}$ is the absorbance of the background (colour of the sample), and $A_{\text {blank }}$ is the absorbance of blank (deionized water).

\section{Fractionation and enrichment of the chicken feather meal peptide hydrolysate}

Molecular mass cut-off by ultrafiltration

The chicken feather meal peptide hydrolysate was fractionated through ultrafiltration membranes with molecular mass cut-off (MMCO; Pellicon XL filter; Merck Millipore, Billerica, MA, USA) values of $10,5,3$ and $0.65 \mathrm{kDa}$ to give five different size fractions of $>10,5-10,3-5,0.65-3$ and $<0.65 \mathrm{kDa}$. The obtained protein hydrolysate fractions were stored at $-20^{\circ} \mathrm{C}$ until further use.

\section{Gel filtration chromategraphy}

The fraction with the highest NO radical scavenging activity from the ultrafiltration step (i.e. $<0.65 \mathrm{kDa}$ fraction) was loaded onto a preparative Sephacryl S-100 gel filtration column $\left(1.6 \mathrm{~cm} \times 60 \mathrm{~cm}\right.$, AKTA $^{\mathrm{TM}}$ prime with Hitrap ${ }^{\mathrm{TM}}$; Amersham Biosciences, Uppsala, Sweden). The samples were eluted in distilled water at a flow rate of $0.5 \mathrm{~mL} / \mathrm{min}$ and collected in 5-mL fractions (Fraction Collector Frac-950; Amersham
Biosciences), and the absorbance was monitored at $A_{280 \mathrm{~nm}}$ to determine protein concentration. Fractions in each protein peak were pooled and the resulting separate fractions $\left(F_{1}\right.$ to $\mathrm{F}_{4}$ ) were assayed for NO radical scavenging activity.

\section{$R P-H P L C$}

The protein fraction obtained by gel filtration chromatography with the highest NO radical scavenging activity $\left(\mathrm{F}_{2}\right)$ was further fractionated by RP-HPLC using a C18 column (250 $\mathrm{mm} \times 4.6 \mathrm{~mm}$, Luna 5U; Phenomenex, Torrance, CA, USA). The peptides were eluted at room temperature using a gradient (0-100\% mobile phase $B$ for $20 \mathrm{~min}$ ) of mobile phase $\mathrm{A}(0.1 \%$, $V / V$, trifluoroacetic acid; TFA) and B (70\%, V/V, ACN in $0.05 \%$, $V / V$, TFA) at a flow rate of $0.7 \mathrm{~mL} / \mathrm{min}$. Chromatographic analyses were performed using the ChromQuest software (Thermo Fisher Scientific Inc., Waltham, MA, USA) (22). Peptides were detected by measuring the absorbance at $A_{280 \mathrm{~nm}}$, the principal subfractions $\left(F_{2-1}\right.$ to $\left.F_{2-5}\right)$ were isolated and collected, and the NO radical scavenging activity of three aliquots was determined while the rest was lyophilized.

\section{Identification of anti-inflammatory peptides}

The principal subfractions (enriched peptides) obtained from the RP-HPLC fractionation that showed a marked NO radical scavenging activity and a sufficient yield $\left(F_{2-1}\right.$ to $F_{2-3}$ and $F_{2-5}$ ) were identified by amino acid sequencing using quadrupole time-of-flight (Q-TOF) liquid chromatography-tandem mass spectrometry (Q-TOF LC-MS/MS) coupled with electrospray ionization (ESI; model Amazon SL, Bruker, Bremen, Germany). The MS/MS data were searched against the SwissProt database with the MASCOT package (www.matrixscience.com) (23).

\section{Comparison between the NO radical scavenging activity of the pure synthetic peptide and enriched enzymatic subfraction}

The peptide sequences obtained from the Q-TOF LC-MS/ MS ESI analysis were synthesized using a 433A Synergy solid phase peptide synthesizer (model ABI 433A; Applied Biosystems, Foster City, CA, USA). The purity of the peptides was verified by analytical mass spectrometry (model Finnigan ${ }^{\mathrm{TM}} \mathrm{LXQ}^{\mathrm{TM}}$; Thermo Fisher Scientific Inc., Waltham) coupled to a Surveyor HPLC. Ionization was performed in the positive mode. The separation was performed at a flow rate of $100 \mathrm{~m} / \mathrm{min}$ under a linear gradient of $5-80 \%$ B for 50 min, where A was $0.1 \%$ (V/V) formic acid in water and B was $100 \%$ ACN. Mass spectral data from 300-1500 m/ $\mathrm{z}$ were collected in positive ionization mode and HyStar v. 3.2 software (Bruker Daltonics Inc., Billerica, MA, USA) (24) was used to interface the HPLC and MS systems. All data obtained from LC-MS/MS were analysed using de novo sequencing. The NO radical scavenging activity of the pure synthesized peptides was determined in comparison with those obtained from the RP-HPLC fractionation. 


\section{Cell culture}

The RAW 264.7 cell line was maintained in complete medium (CM: DMEM supplemented with $10 \%, V / V, F B S, 100 \mathrm{U} / \mathrm{mL}$ penicillin $\mathrm{G}, 0.4 \mathrm{mg} / \mathrm{mL}$ streptomycin sulfate, $1 \%, \mathrm{~m} / \mathrm{V}$, sodium pyruvate and $1 \%, m / V$, HEPES) at $37^{\circ} \mathrm{C}$ in a humidified atmosphere with $5 \%(V / V) \mathrm{CO}_{2}$. For routine maintenance in the culture (passage) (22), the cells were seeded in non-tissue culture treated dishes at approx. $10 \%$ confluency and grown to approx. $80 \%$ confluency, which typically took 2 days. The used medium was aspirated, cells were gently rinsed with PBS, then dislodged by gently scraping with a rubber spatula and harvested by centrifugation (Hettich, Tuttlingen, Germany) at $15000 \times g$ and $4{ }^{\circ} \mathrm{C}$ for $5 \mathrm{~min}$.

\section{Pretreatment of macrophage RAW 264.7 cells}

The macrophage RAW 264.7 cells were seeded in 96-well plates at $N=10^{4}$ cells/well in $100 \mu \mathrm{L} \mathrm{CM}$ and incubated overnight at $37{ }^{\circ} \mathrm{C}$ in a humidified atmosphere with $5 \% \mathrm{CO}_{2}$. The medium was replaced with $\mathrm{CM}$ alone (negative control) or with different concentrations of the chicken feather meal protein hydrolysate (or fractions thereafter), or with budesonide $(2.5 \mu \mathrm{g} / \mathrm{mL})$ as a positive control, and incubated for $1 \mathrm{~h}$. NO production was stimulated by the addition of $100 \mathrm{ng} / \mathrm{mL}$ of LPS and incubated for $12 \mathrm{~h}$.

\section{Measurement of cell viability/proliferation by the MTT assay}

The cytotoxicity activity of the $\mathrm{F}_{2}$ and the peptide from $F_{2-1}$ (SNPSVAGVR) were determined according to Saisavoey et al. (22) with slight modifications. The macrophage RAW 264.7 cells were plated at $N=10^{4}$ cells/well in a 96-well plate and then incubated at $37^{\circ} \mathrm{C}$ with $5 \%(V / V) \mathrm{CO}_{2}$ for $24 \mathrm{~h}$. Cells were then treated with different concentrations of the test sample (peptide) and LPS. Subsequently, $100 \mu \mathrm{L}$ of a $5 \mathrm{mg} / \mathrm{mL}$ MTT solution (in PBS) were added to each well. Cells were incubated at $37{ }^{\circ} \mathrm{C}$ in a humidified atmosphere with $5 \% \mathrm{CO}_{2}$ for $4 \mathrm{~h}$ before the medium was removed and DMSO added at $100 \mu \mathrm{L} /$ well to solubilise the formed formazan crystals, and subsequently the $A_{540 \mathrm{~nm}}$ was measured (model Multiskan GO; Thermo Fisher Scientific Inc.).

\section{Determination of NO production by macrophage RAW 264.7 cells}

The level of NO production was determined by measuring nitrite production in the CM according to the Griess reaction. Macrophage RAW 264.7 cells were incubated with the test sample at various concentrations (control $0 \mu \mathrm{g} / \mathrm{mL}$ ). Then $50 \mu \mathrm{L}$ of sulfanilamide were added to $50 \mu \mathrm{L}$ of the culture supernatant in a 96-well plate and incubated at room temperature for $10 \mathrm{~min}$ before $50 \mu \mathrm{L}$ of the NED solution were added and incubated for $10 \mathrm{~min}$. Finally, the $A_{540 \mathrm{~nm}}$ was measured using a microplate reader (model Multiskan GO; Thermo Fisher Scientific Inc.).
Detection of iNOS, TNF- $a$, COX-1, COX-2 and IL-6 mRNA by two-stage reverse transcriptase (RT)-PCR or quantification by two-stage quantitative real time (qrt)-RT-PCR analyses

Macrophage RAW 264.7 cells were pretreated for $1 \mathrm{~h}$ with a solvent (negative control), and synthesized peptide at various concentrations or $2.5 \mu \mathrm{g} / \mathrm{mL}$ of budesonide (positive control). The pretreated cells were then stimulated by the addition of $100 \mathrm{ng} / \mathrm{mL}$ of LPS and incubated for $12 \mathrm{~h}$ before their total RNA was harvested using the MasterPure ${ }^{\mathrm{TM}}$ Complete DNA and RNA Purification Kit (Epicentre; Lucigen, a part of LGC, Biosearch Technologies, Middleton, WI, USA) according to the manufacturer's instruction. The RNA concentration was measured using a Nanodrop 2000 UV-Vis spectrophotometer (Thermo Fisher Scientific, Inc.) at $260 \mathrm{~nm}$. Reverse transcription of the total RNA $(1 \mu \mathrm{g})$ was performed with oligo-dT primers using a Precision nanoScript II Reverse Transcription Kit (PrimerDesign, Camberley, UK) according to the manufacturer's protocol. The PCR was performed using selective primers for the $\beta$-actin ( $5^{\prime}$ - ACCAACTGGGACGACATGGAGAA- 3 ' and 5'-GTGGTGGTGAAGCTGTAGCC-3'), iNOS (5'- CCATCATGGACCACCACACA-3' and 5'-CCATGCAGACAACCTTGGTG-3'), IL-6 (5'- CATGTTCTCTGGGAAATCGTGG-3' and 5'-AACGCACTAGGTTTGCCGAGTA-3'), TNF-a (5'-CCTGTAGCCCACGTCGTAGC-3' and 5'-TGACCTCAGCGCTGAGTTG-3'), COX-1 (5'- AGTGCGGTCCAACCTTATCC- 3 ' and $5^{\prime}$ - GGTAAAGCCAGGACCCATCTTTC- $3^{\prime}$ ), and COX-2 (5'- GGAGAGACTATCAAGATAGT-3' and 5'- ATGGTCAGTAGACTTTTACA-3').

For the (qrt)-RT-PCR analysis, the PCR mixture comprised $1 \mu \mathrm{L}$ cDNA, $1 \mu \mathrm{L}$ of each primer (10 mM), $7 \mu \mathrm{L}$ ultrapure water and $10 \mu \mathrm{L} 2 \times$ qPCRBIO SyGreen Mix (PCR Biosystems Ltd, London, UK) to give a final volume of $20 \mu \mathrm{L}$. The (qrt)-RTPCR reactions (performed separately per gene) were amplified using a MyGo Pro ${ }^{\circledast}$ Real time PCR apparatus (IT-IS International Ltd, Stokesley, UK) and thermal cycles at $95^{\circ} \mathrm{C}$ for 2 min, followed by 40 cycles at $95^{\circ} \mathrm{C}$ for $10 \mathrm{~s}, 68^{\circ} \mathrm{C}$ (or $60^{\circ} \mathrm{C}$ for TNF- $a$ and IL-6) for $20 \mathrm{~s}$ and $72^{\circ} \mathrm{C}$ for $30 \mathrm{~s}$ with melting at 55$95^{\circ} \mathrm{C}$ for $1 \mathrm{~min}$. The RT-PCR was performed using selective primers for the $\beta$-actin ( $5^{\prime}$-GATCAAGATCATTGCTCCTCCTG-3' and $5^{\prime}$-CGCAGCTCAGTAACAGTCCG-3'), iNOS (5'-CGGCAAACATGACTTCAGGC-3' and 5'-TAGGTCGATGCACAACTGGG-3'), IL-6 (5'-CTCTCTGCAAGAGACTTCCATCC-3' and 5'-ACAGGTCTGTTGGGAGTGGTATC-3'), TNF-a (5'-GGGCAGGTCTACTTTGGAGTCA-3' and 5'-ACAGACTGGGGGCTCTGAGG-3'), COX-1 (5'-AGCTGCTGCTGAGAAGGGAGTT-3' and 5'-GGTAAAGCCAGGACCCATCTTTC-3'), and COX-2 (5'-CTGACCCCCAAGGCTCAAAT- $3^{\prime}$ and $5^{\prime}$-AAGTCCACTCCATGGCCCAG $-3^{\prime}$ ). $\beta$-Actin was used as the internal reference gene and the three q-PCR reactions were analysed by relative quantitation. The relative gene expression level was determined using the $\mathrm{Ct}$ (threshold cycle) value by calculating as follows:

$$
\text { Relative gene expression }=2^{-\Delta \Delta C t}
$$

where $\Delta \Delta \mathrm{Ct}$ correlates with the increase in the threshold cycle of the gene (25). 


\section{Statistical analysis}

Numerical data are shown as the mean value \pm standard deviation, derived from three independent repeats. The data were subjected to analysis of variance followed by Duncan's multiple range post hoc tests, accepting significance at the $p<0.05$ level. The analysis was performed using the SPSS statistical software (26).

\section{RESULTS AND DISCUSSION}

\section{Amino acid composition of chicken feather meal}

The chicken feather meal contains essential and non-essential amino acids (Table 1). Glutamic acid, proline, serine, glycine and leucine are present in higher mass fractions than other amino acids. Active anti-inflammatory peptides from Mytilus coruscus were reported to consist of glycine, valine, serine, leucine, glutamine and phenylalanine (5,27). Moreover, it was reported that peptides consisting of glycine, cysteine, alanine, valine and serine could inhibit NO production, while peptides comprising glycine, cysteine and histidine exhibited anti-inflammatory activity by inhibiting the NF-KB signalling pathway (28). Certain amino acids, such as glycine, histidine, cysteine, glutamine and tryptophan, have been reported to possess anti-inflammatory properties (29).

\section{In vitro NO radical scavenging assay}

The anti-inflammatory activity of the crude protein hydrolysates of chicken feather meal from the three protease digests was tested using a NO radical scavenging assay. NO radical scavenging activity of hydrolysates obtained with $\mathrm{Al}$ calase and Neutrase increased with the increase of enzyme concentration up to $25 \mathrm{mg} / \mathrm{mL}$, and then at $50 \mathrm{mg} / \mathrm{mL}$ the activity decreased. However, a dramatically increased $\mathrm{NO}$ radical

Table 1. Amino acid profile of chicken feather meal

\begin{tabular}{lc} 
Amino acid & w/\% \\
Alanine (Ala) & 3.80 \\
Arginine (Arg) & 6.30 \\
Glycine (Gly) & 6.82 \\
Aspatic acid (Asp) & 5.70 \\
Cysteine (Cys) & 2.90 \\
Glutamic acid (Glu) & 10.6 \\
Leucine (Leu) & 6.46 \\
Isoleucine (Ile) & 3.94 \\
Histidine (His) & 0.59 \\
Threonine (Thr) & 3.96 \\
Proline (Pro) & 8.37 \\
Lysine (Lys) & 1.45 \\
Methionine (Met) & 0.67 \\
Serine (Ser) & 7.84 \\
Phenylalanine (Phe) & 4.03 \\
Tyrosine (Tyr) & 1.10 \\
Tryptophan (Trp) & 0.20 \\
Valine (Val) & 5.85 \\
Total & 80.58 \\
\hline
\end{tabular}

scavenging activity was observed after treatment with $10 \mathrm{mg} /$ $\mathrm{mL}$ Flavourzyme (Table 2). Overall, the hydrolysate obtained with $10 \mathrm{mg} / \mathrm{mL}$ Flavourzyme exhibited the highest NO radical scavenging activity, with an $\mathrm{IC}_{50}=(5.5 \pm 1.0) \mu \mathrm{g} / \mathrm{mL}$. Several studies have suggested that the antioxidant activity of peptides in hydrolysates varies depending on their amino acid composition, sequence and length (30). This suggests that enzymatic hydrolysis with different proteolytic enzymes and conditions would lead to the formation of different peptide sequences. In the same way, the anti-inflammatory activity of the Flavourzyme hydrolysate from M. coruscus showed a strong inhibition of NO production in macrophage RAW 264.7 cells (27). Since the hydrolysate obtained from chicken feather meal with $10 \mathrm{mg} / \mathrm{mL}$ Flavourzyme had the highest NO radical scavenging activity, it was selected for further study.

Table 2. Effect of enzyme concentration on NO radical scavenging activity of chicken feather meal hydrolysates expressed as concentration of hydrolysate that inhibited $50 \%$ of NO production $\left(\mathrm{IC}_{50}\right)$

\begin{tabular}{lcccc} 
& \multicolumn{4}{c}{$\gamma($ enzyme $) /(\mu \mathrm{g} / \mathrm{mL})$} \\
\cline { 2 - 5 } Enzyme & 0 & 10 & 25 & 50 \\
\cline { 2 - 5 } & \multicolumn{4}{c}{$\mathrm{IC}_{50} /(\mu \mathrm{g} / \mathrm{mL})$} \\
Alcalase & $(134.0 \pm 4.7)^{\mathrm{e}}$ & $(80.6 \pm 5.4)^{\mathrm{d}}$ & $(30.0 \pm 1.8)^{\mathrm{a}}$ & $(40.2 \pm 0.8)^{\mathrm{b}}$ \\
Flavourzyme & $(158.4 \pm 1.5)^{\mathrm{E}}$ & $(5.5 \pm 1.0)^{\mathrm{A}}$ & $(82.1 \pm 7.0)^{\mathrm{D}}$ & $(68.7 \pm 3.6)^{\mathrm{C}}$ \\
Neutrase & $(175.7 \pm 4.0)^{\mathrm{ee}}$ & $(133.0 \pm 5.4)^{\mathrm{dd}}$ & $(37.0 \pm 0.4)^{\text {aa }}$ & $(78.7 \pm 3.9)^{c \mathrm{cc}}$ \\
\hline
\end{tabular}

Data are shown as mean value \pm standard deviation of triplicates. Different superscripts indicate significant difference $(p<0.05)$. Curcumin was used as positive control $\left(\mathrm{IC}_{50}=(60.5 \pm 3.2) \mu \mathrm{g} / \mathrm{mL}\right)$

\section{Enrichment of NO inhibitory peptides from the chicken} feather meal hydrolysate obtained with $10 \mu \mathrm{g} / \mathrm{mL}$ Flavourzyme

The $50 \%$ inhibitory concentrations of the obtained $>10$, $5-10,3-5,0.65-3$ and $<0.65 \mathrm{kDa}$ fractions were $(21.9 \pm 0.7)$, $(10.4 \pm 0.7),(7.2 \pm 0.5),(5.8 \pm 0.6)$ and $(3.6 \pm 0.3) \mu \mathrm{g} / \mathrm{mL}$ respectively (Table S1). Thus, it can be concluded that the inhibitory activity increased with the decrease of peptide fraction size. The molecular mass is an important parameter that correlates with the bioactivity of protein hydrolysates. Previous research has shown that the effective hydrolysates depend on their molecular mass distribution, e.g. Li et al. (31) reported that the peptide fraction with a molecular mass of 200-3000 Da was probably associated with a higher antioxidant activity, Nalinanon et al. (32) reported that low molecular mass peptides contributed to the antioxidant activity, and Wang et al. (33) reported that the biological activity of hydrolysates depended on the molecular mass of each peptide.

Arrays of NO inhibitory peptides with low molecular mass fractionated by ultrafiltration were previously shown to be effective in interacting with internal barriers to promote biological activities including antioxidant and anti-inflammatory activities (34). In addition, Lee et al. (35) also identified low molecular mass $(<1.3 \mathrm{kDa})$ anti-inflammatory egg white peptides that were able to attenuate the symptoms of inflammatory bowel 
a)

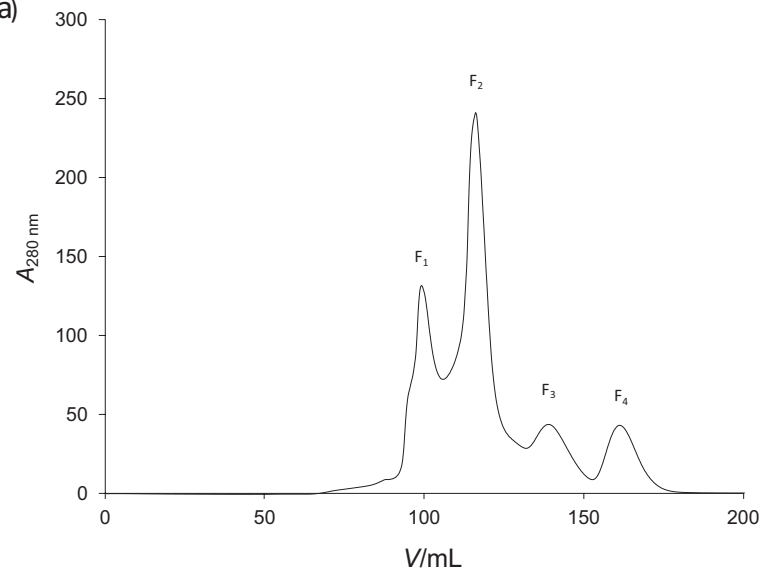

b)

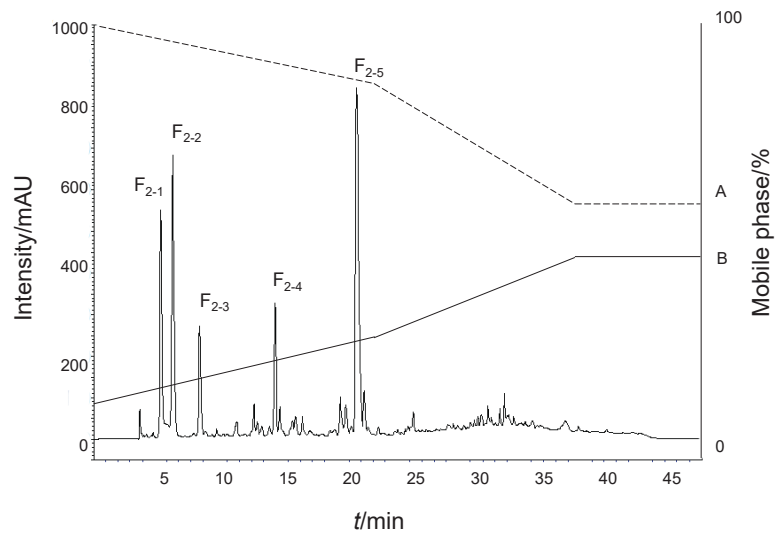

Fig. 1. Enrichment of bioactive peptides from the $<0.65 \mathrm{kDa}$ fraction of chicken feather meal hydrolysate obtained with $10 \mathrm{mg} / \mathrm{mL}$ Flavourzyme: a) the absorbance values of four fractions obtained after gel filtration chromatography of bioactive peptide, and b) RP-HPLC chromatograph of the $F_{2}$ fractionation into five principal subfractions $\left(F_{2-1}\right.$ to $\left.F_{2-5}\right)$

disease. Anti-inflammatory Leu-Asp-Ala-Val-Asn-Arg (683 Da) and Met-Met-Leu-Asp-Phe (655 Da) from Spirulina maxima (11), Gln-Cys-Gln-Gln-Ala-Val-Gln-Ser-Ala-Val (1061 Da) from Ruditapes philippinarum (5) and Gln-Cys-Gln-Cys-Ala-Val-GluGly-Gly-Leu (1007 Da) from Crassostrea gigas were also isolated from marine organisms (36), while the tripeptide Val-Pro-Tyr (377 Da) from soybean exhibited anti-inflammatory effects (37). Therefore, the $<0.65 \mathrm{kDa}$ fraction from chicken feather meal was selected for further study.

Since peptide length is closely related to biological activities (antioxidant, antihypertensive, antimicrobial and immunomodulatory), gel filtration chromatography is suitable for fractionation, enrichment and concentration of proteins and peptides (Fig. 1). It has previously been reported to be useful for improving the anticancer activities of protein hydrolysates (38). Thus, further separation of lyophilized active $<0.65 \mathrm{kDa}$ fraction yielded four $\left(F_{1-4}\right)$ protein fractions based upon segregation of the $A_{280 \mathrm{~nm}}$ profile (Fig. 1a). Measurement of NO inhibitory activity of each of the four fractions revealed that $F_{1}$ and
$F_{2}$ had NO inhibitory activity with $\mathrm{IC}_{50}$ values of $(73.5 \pm 2.8)$ and (34.6 \pm 3.4$) \mu \mathrm{g} / \mathrm{mL}$ (Table S2), respectively, whereas the yields of fractions $\mathrm{F}_{3}$ and $\mathrm{F}_{4}$ were too low to determine their $\mathrm{IC}_{50}$ values.

Given the higher inhibitory activity (lower $I C_{50}$ value) of fraction $F_{2}$, it was selected for further fractionation. The $F_{2}$ fraction was divided into five principal subfractions $\left(\mathrm{F}_{2-1}, \mathrm{~F}_{2-2,}, \mathrm{~F}_{2-3}, \mathrm{~F}_{2-4}\right.$ and $F_{2-5}$ ) (Fig. $1 b$ ) all with NO radical scavenging activity. The yield of subfraction $\mathrm{F}_{2-4}$ was too low to determine its $\mathrm{IC}_{50}$ value, while the $I C_{50}$ values of the remaining four fractions were: (16.8 \pm 1.5$)$, (15.3 \pm 0.7$),(17.4 \pm 0.4)$ and $(34.0 \pm 1.9) \mu \mathrm{g} / \mathrm{mL}$ (Table S3), respectively, and they were subjected to amino acid sequencing by mass spectrometry.

Identification of peptides by Q-TOF mass spectrometry and comparison of the NO radical scavenging activity between synthetic and enzymatic peptides

The amino acid sequences and molecular masses of $\mathrm{F}_{2-11}$ $F_{2-2}, F_{2-3}$ and $F_{2-5}$ are shown in Table 3 . The de novo sequencing

Table 3. Amino acid sequences of RP-HPLC subfractions obtained from the chicken feather meal hydrolysate, identified by Q-TOF LC/MS/MS

\begin{tabular}{|c|c|c|c|c|c|}
\hline Fraction & Amino acid sequence & $\mathrm{M} / \mathrm{Da}$ & Protein name & Organism & Accession number \\
\hline \multirow[t]{5}{*}{$F_{2-1}$} & SNPSVAGVR & 886 & Putative E3 ubiquitin-protein ligase SH3RF2 & Gallus gallus & XP_015157384.1 \\
\hline & & & Putative E3 ubiquitin-protein ligase SH3RF2 ioform X2 & Gallus gallus & XP_015157384.1 \\
\hline & & & Putative E3 ubiquitin-protein ligase SH3RF2 isoform X1 & Gallus gallus & XP_414662.3 \\
\hline & & & PRELI domain containing protein 3B & Gallus gallus & NP_001026037.1 \\
\hline & & & Hypothetical protein RCJMB04_17b4, partial & Gallus gallus & CAG32065.1 \\
\hline$F_{2-2}$ & SLFLHTHSIVADK & 1468 & Lactate dehydrogenase & Phodilus badius & GI629677270 \\
\hline \multirow[t]{5}{*}{$F_{2-3}$} & AVLKKKVTSTFGR & 1435 & Cystine/glutamate transporter & Gallus gallus & XP_426289.3 \\
\hline & & & Dynein heavy chain 1 , axonemal & Gallus gallus & XP_015148334.1 \\
\hline & & & Unconventional myosin-XVI isoform X2 & Gallus gallus & XP_004938593.1 \\
\hline & & & Unconventional myosin-XVI isoform $\mathrm{X} 1$ & Gallus gallus & XP_416950.3 \\
\hline & & & Transcription initiation factor TFIID subunit 9B & Gallus gallus & NP_001264725.1 \\
\hline \multirow[t]{5}{*}{$\mathrm{F}_{2-5}$} & LSPWPVKGV & 982 & Zinc finger matrin-type protein 1 -like isoform X1 & Gallus gallus & XP_004936323.1 \\
\hline & & & Neogenin isoform X6 & Gallus gallus & XP_015134538.1 \\
\hline & & & Neogenin isoform X5 & Gallus gallus & XP_015134537.1 \\
\hline & & & Neogenin isoform $\mathrm{X} 4$ & Gallus gallus & XP_015134536.1 \\
\hline & & & Neogenin isoform $X 3$ & Gallus gallus & XP_015134535.1 \\
\hline
\end{tabular}


yielded a homology identification of $100 \%$ based on the Phasianidae family. Each sequence contained 9-13 amino acid residues. Fraction $\mathrm{F}_{2-1}$ was identified as Ser-Asn-Pro-Ser-Val-Ala-Gly-Val-Arg (SNPSVAGVR; 886 Da), $F_{2-2}$ as Ser-Leu-Phe-Leu-His-Thr-His-Ser-lle-Val-Ala-Asp-Lys (SLFLHTHSIVADK; $1468 \mathrm{Da}), \mathrm{F}_{2-3}$ as Ala-Val-Leu-Lys-Lys-Lys-Val-Thr-Ser-Thr-Phe-Gly-Arg (AVLKKKVTSTFGR; $1435 \mathrm{Da}$ ) and $\mathrm{F}_{2-5}$ as Leu-Ser-Pro-Trp-Pro-Val-Lys-Gly-Val (LSPWPVKGV; $982 \mathrm{Da}$ ).

Since $F_{2-1}, F_{2-2}, F_{2-3}$ and $F_{2-5}$ exhibited NO radical scavenging activity, these obtained peptide sequences were synthesized and evaluated for their NO radical scavenging activity. However, the SNPSVAGVR peptide showed a high NO radical scavenging activity with an $\mathrm{IC}_{50}$ value of $(55.2 \pm 0.2) \mathrm{mM}$ (Table S4). Regarding the relationship between the properties and anti-inflammatory activity of the amino acids, all of the peptide sequences contained mainly hydrophobic (leucine, histidine, phenylalanine, proline, tryptophan and valine) and positively charged (arginine and lysine) amino acids. These have been reported previously to have a high antioxidant activity (39). Hasegawa et al. (28) reported the anti-inflammatory activity of glycine and histidine, suggesting that glycine, histidine and cysteine act as anti-inflammatory agents by reducing NF-KB activation and inhibiting the expression of IL-6 in human coronary arterial endothelial cells. The relationships between the structure and the activity of the peptides and their mechanism of anti-inflammatory activities are not yet fully understood. However, the inhibition of NO production (\%) by these peptides might be related to their amino acid composition and sequences since hydrophobic amino acid sequences in peptides have been suggested to play important roles in anti-inflammatory activities (40).

\section{Anti-inflammatory effect of the $F_{2}$ fraction in LPS-induced macrophage RAW 264.7 cells}

The $F_{2-1}$ fraction showed no cytotoxicity to LPS-induced RAW 264.7 cells up to the highest tested concentration (120 $\mu \mathrm{g} / \mathrm{mL})$, where a cell viability of $(92.6 \pm 0.6) \%$ was still observed (Fig. 2a). Thus, the $F_{2-1}$ fraction can be used at concentrations up to $120 \mu \mathrm{g} / \mathrm{mL}$. Likewise, the bioactive peptides of Lupinus angustifolius were previously shown not to be cytotoxic against RAW 264.7 cells (41). Therefore, the nontoxic $F_{2-1}$ peptide was evaluated further by testing its $\mathrm{NO}$ inhibitory activity.

In this study, an inflammation-type response was created in RAW 264.7 cells by treating them with $100 \mathrm{ng} / \mathrm{mL}$ LPS. The NO released from the LPS-stimulated RAW 264.7 cells was found to decrease with increasing concentrations of $F_{2-1}(2.5-40 \mu \mathrm{g} /$ $\mathrm{mL}$ ), where LPS treatment alone was considered as the control ( $P$ in Fig. 2b). The enriched $F_{2-1}$ peptide significantly inhibited NO production: at the concentration of $5 \mu \mathrm{g} / \mathrm{mL}$ by $<15 \%$ and at $20 \mu \mathrm{g} / \mathrm{mL}$ by $>85 \%$ (Fig. 2b). Peptides derived from marine sources were previously shown to possess NO inhibitory activities, such as the lupine protein hydrolysate from $L$. angustifolius in LPS-stimulated THP-1 cells (41) and R. philippinarum (5) and M. coruscus (27) in LPS-stimulated RAW264.7 cells. Both NO and proinflammatory cytokines play a critical role in the physiology

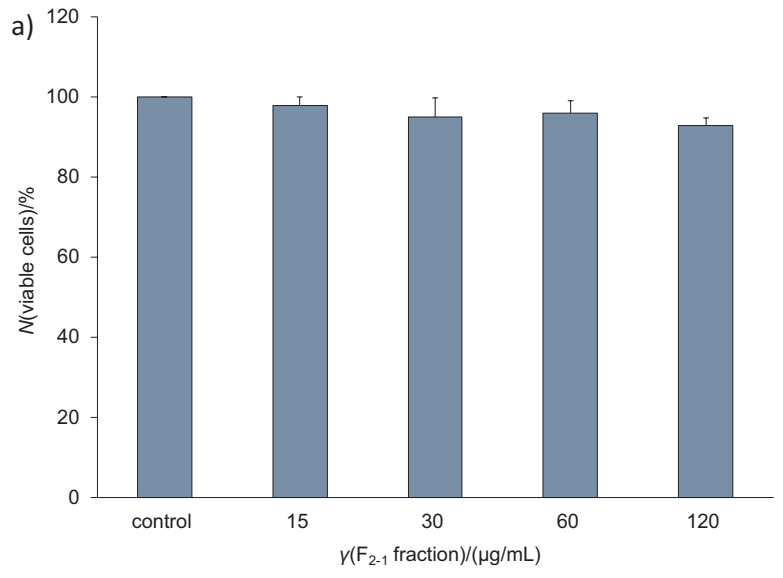

b)

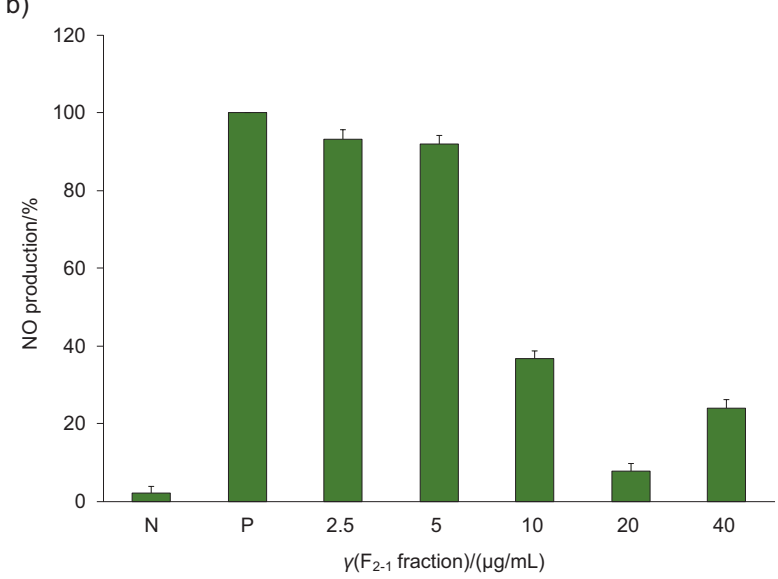

Fig. 2. Effect of different concentrations of $F_{2-1}$ fraction on: a) viability of and b) NO production by lipopolysaccharide (LPS)-stimulated RAW 264.7 macrophage cells, where $N$ and $P$ represent the negative (cells alone) and positive (cells+LPS) controls respectively

and pathology of diverse tissues, including the immune system of the body.

Fig. 3 showed that in unstimulated macrophage RAW 264.7 cells the transcript levels of iNOS, COX-2, TNF- $a$ and IL- 6 were undetectable, but they were all expressed after treatment with LPS, and the $F_{2-1}$ fraction significantly inhibited these expression levels without affecting the constitutive expression of COX-1 and $\beta$-actin transcripts. Cotreatment of the RAW 264.7 cells with LPS and $F_{2-1}$ fraction still revealed the upregulation of COX-2 and TNF- $a$, whereas the expression of IL- 6 and iNOS transcripts was downregulated. On the other hand, cotreatment with $\mathrm{F}_{2-1}$ fraction negated the LPS-induced expression of COX-2 and TNF- $\alpha$ as well as IL- 6 and iNOS. It is known that iNOS responds to various proinflammatory cytokines, including INF- $\gamma$, TNF- $\alpha$ and IL-6, and mediates several inflammatory responses (42). Moreover, it has been reported that the inducible isoforms of NOS and COX-2 are involved in the production of large amounts of $\mathrm{NO}$ and $\mathrm{PGE}_{2}$, respectively (43). The activation of NF-KB is responsible for the induced expression of iNOS and COX-2 (44).

Oxidative stress has been reported to promote inflammation-related diseases through activation of the NF-KB pathway (45). Therefore, an antioxidative effect is a possible mechanism of limiting the damage induced by inflammatory reactions, 


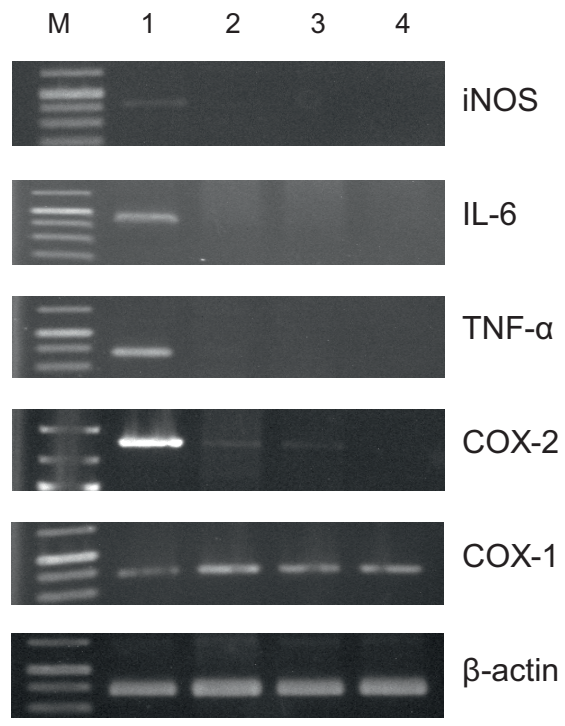

Fig. 3. Effect of $F_{2-1}$ fraction on transcript expression levels of iNOS, IL-6, TNF-a, COX-1, COX-2 and $\beta$-actin in lipopolysaccharide (LPS)-induced RAW 264.7 macrophage cells. Lane $1=\mathrm{LPS}$, lane $2=\mathrm{LPS}+\gamma\left(\mathrm{F}_{2-1}\right.$ fraction) $=40 \mu \mathrm{g} / \mathrm{mL}$, lane $3=L P S+$ budesonide; $2.5 \mu \mathrm{g} / \mathrm{mL}$ (positive control), lane $4=$ no addition of LPS or $F_{2-1}$ and lane $M=1000$-bp size markers

although a detailed mechanism remains unclear. The NO radical scavenging assays in both in vitro and cellular models indicated that all the chicken feather meal hydrolysate-based fractions, especially fraction $\mathrm{F}_{2-1}$, can potentially impair oxidative stress. The effects of peptide length or peptide mixture were not observed in the cellular anti-inflammatory assays, and this could be due to complex interactions of the constituents in each hydrolysate with the cell matrices, and the likelihood of further proteolytic processing of the peptides within the cell cultures.

Several studies have reported anti-inflammatory activities of low-molecular-mass peptides derived from food proteins, such as soybean (46), milk (47), soybean flour (48), egg (49) and whey (50). However, a high-molecular-mass peptide lunasin derived from soybean was reported to down-regulate the production of IL-6, IL-1 $\beta, N F-k B$, iNOS and NO, indicating an anti-inflammatory function (46). Moreover, other factors, such as the peptide sequence and amino acid composition (not evaluated for all the hydrolysates in this study), can also determine the bioactivity of protein hydrolysates. This activity could be due to electron donation by the sulfhydryl group of cysteine leading to dimerization, although this mechanism would be more relevant in free radical quenching than ROS scavenging. Therefore, the structure-function relationships of antioxidative and anti-inflammatory peptides and protein hydrolysates appear complex, especially within physiological matrices.

\section{Anti-inflammatory activity of the synthesized SNPSVAGVR peptide}

The SNPSVAGVR peptide displayed no cytotoxic effect against the RAW 264.7 cells at various concentrations
(15-120 mM), as shown in Fig. 4a. Stimulation of RAW264.7 cells with LPS $(100 \mathrm{ng} / \mathrm{mL})$ resulted in a significant increase in NO production compared to the unstimulated group, and SNPSVAGVR inhibited this NO production in a dose-dependent manner (Fig. 4b). The potential mechanism underlying the anti-inflammatory activity of SNPSVAGVR in LPS-induced RAW 264.7 macrophages was evaluated in terms of the transcript expression level of proinflammatory mediators. As shown in Fig. 5, LPS treatment markedly stimulated the expression of iNOS, IL-6, TNF- $a$ and COX-2 (but not COX-1) in RAW 264.7 cells. When added to the cells, $60 \mathrm{mM}$ of SNPSVAGVR blocked the stimulatory effects of LPS on these genes (at $p<0.05$ and $p<0.001$ ). It is known that IL- 6 and COX-2 have important effects on inflammation, and so it is relevant that SNPSVAGVR at $60 \mathrm{mM}$ clearly decreased the IL- 6 and COX-2 transcript expression levels by 96 and $83 \%$ respectively. All of these results support the conclusion that the synthetic peptide had in vitro anti-inflammatory effect.
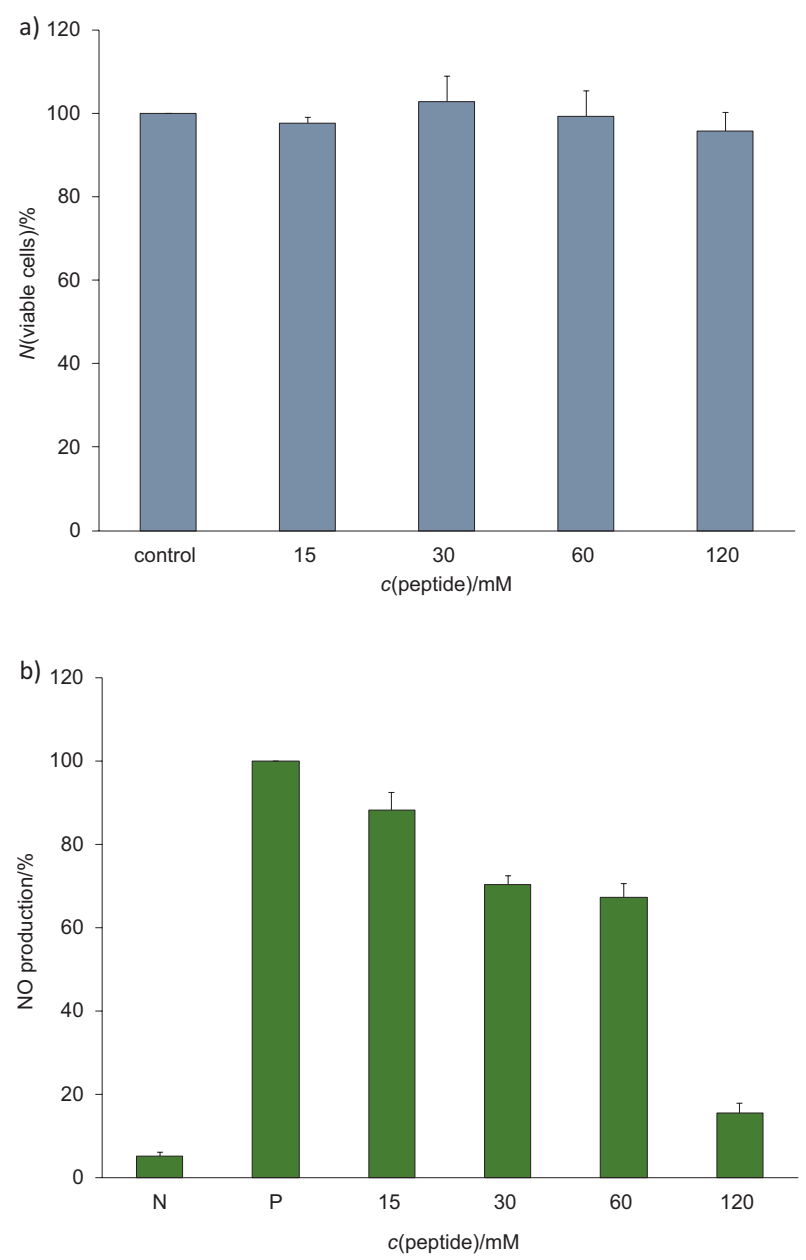

Fig. 4. Effect of different concentrations of synthesized SNPSVAGVR peptide on: a) viability of and b) NO production by lipopolysaccharide (LPS)-stimulated RAW 264.7 macrophage cells, where $\mathrm{N}$ and $\mathrm{P}$ represent the negative (cells alone) and positive (cells+LPS) controls respectively 

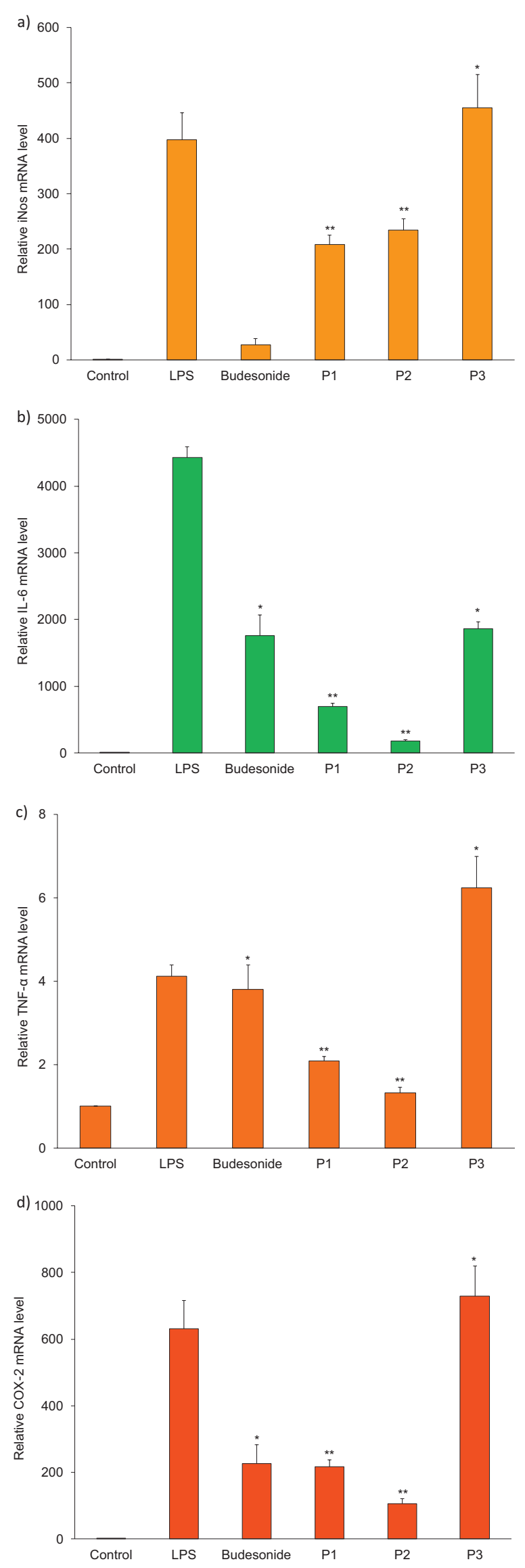

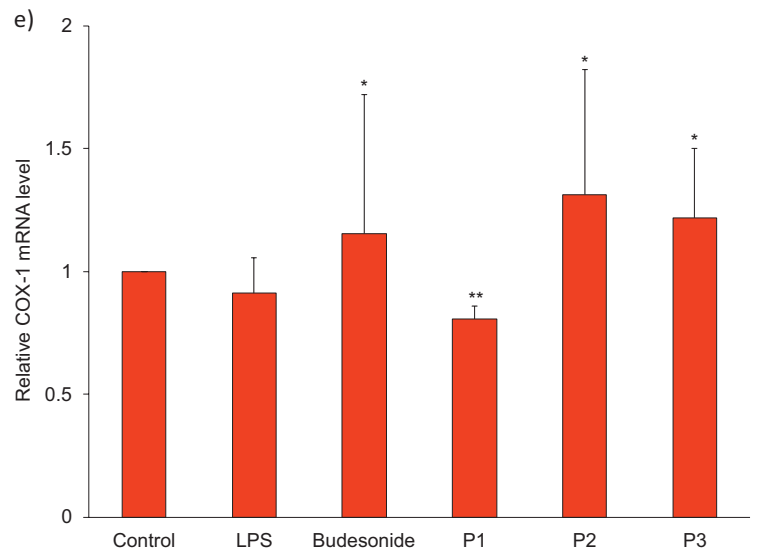

Fig. 5. Effects of synthesized SNPSVAGVR peptide on transcript expression levels of: a) inducible nitric oxide synthase (iNOS), b) interleukin 6 (IL-6), c) tumour necrosis factor (TNF-a), d) cyclooxygenase-2 (COX-2) and e) cyclooxygenase-1 (COX-1) in lipopolysaccharide (LPS)-stimulated RAW264.7 cells measured by qrtRT-PCR. Cells were incubated for $12 \mathrm{~h}$ with $\gamma(\mathrm{LPS})=100 \mathrm{ng} / \mathrm{mL}$ in the presence of $c$ (peptide $)=30\left(P_{1}\right), 60\left(P_{2}\right)$ and $120\left(P_{3}\right) \mathrm{mM}$, or with $\gamma($ budesonide $)=2.5 \mu \mathrm{g} /$ $\mathrm{mL}$ as positive control. Statistical significance is expressed as ${ }^{*} \mathrm{p}<0.05$ and ${ }^{* *} \mathrm{p}<0.001$ compared to LPS

\section{CONCLUSIONS}

Our results show that chicken feather meal peptides obtained by microbial enzyme hydrolysis exhibit anti-inflammatory activity, as evaluated by the NO radical scavenging assay. The chicken feather meal hydrolysate obtained with $10 \mathrm{mg} /$ $\mathrm{mL}$ Flavourzyme had the highest NO radical scavenging activity. Peptides with the lowest molecular mass $(<0.65 \mathrm{kDa})$ have the highest NO radical scavenging activity. Moreover, the $F_{2-1}$ fraction and pure SNPSVAGVR peptide are potent inhibitors of the LPS-induced expression of pro-inflammatory cytokines, including iNOS, TNF-a, COX-2 and IL-6. These results suggest that chicken feather meal hydrolysate can potentially be used as a natural anti-inflammatory agent in functional foods or pharmaceutical products.

\section{ACKNOWLEDGEMENTS}

The authors would like to thank the Institute of Biotechnology and Genetic Engineering, Chulalongkorn University, for their support and providing access to their facilities. The authors thank the Edanz Group (www.edanzediting.com/ac) for editing the draft of this manuscript.

\section{FUNDING}

We acknowledge the financial support from the Research and Researcher for Industry: MAG under grant number MSD5710073, the Grant for Research: Government Budget, Chulalongkorn University under grant number GRB_BSS_ 99_59_61_06, and The Center of Excellence on Medical Biotechnology (CEMB), S\&T Postgraduate Education and Research Development Office (PERDO), Office of Higher Education Commission (OHEC), Thailand (SN-60-003-909) for providing the financial support for this research. 


\section{CONFLICT OF INTEREST}

The authors report no conflict of interest. The authors alone are responsible for the content and writing of this article.

\section{SUPPLEMENTARY MATERIAL}

All supplementary material is available at www.ftb.com.hr.

\section{ORCID IDs}
A. Inkanuwat (1) https://orcid.org/0000-0002-8178-3419
R. Sukaboon (1) https://orcid.org/0000-0002-4649-7433
O. Reamtong (i) https://orcid.org/0000-0002-1154-6485
P. Asawanonda (1) https://orcid.org/0000-0002-2628-0894
A. Pattaratanakun (1) https://orcid.org/0000-0003-1361-5859
T. Saisavoey (1) https://orcid.org/0000-0001-5315-8264
P. Sangtanoo (1) https://orcid.org/0000-0002-6085-1144
A. Karnchanatat (D) https://orcid.org/0000-0002-6598-013X

\section{REFERENCES}

1. Zhou HY, Shin EM, Guo LY, Youn UJ, Bae K, Kang SS, et al. Anti-inflammatory activity of 4-methyxyhonokiol is a function of the inhibition of iNOS and COX-2 expression in RAW 264.7 macrophages via NF-kB, JNK and p38 MAPK inactivation. Eur J Pharmacol. 2008;586(1-3):340-9.

https://doi.org/10.1016/j.ejphar.2008.02.044

2. Wojdasiewicz P, Poniatowski ŁA, Szukiewicz D. The role of inflammatory and anti-inflammatory cytokines in the pathogenesis of osteoarthritis. Mediators Inflamm. 2014;2014:Article ID 561459.

https://doi.org/10.1155/2014/561459

3. Guha M, Mackman N. LPS induction of gene expression in human monocytes. Cell Signal. 2001;13(2):85-94.

https://doi.org/10.1016/S0898-6568(00)00149-2

4. Dia VP, Wang W, Oh VL, de Lumen BO, de Mejia EG. Isolation, purification and characterisation of lunasin from defatted soybean flour and in vitro evaluation of its anti-inflammatory activity. Food Chem. 2009;114(1):108-15.

https://doi.org/10.1016/j.foodchem.2008.09.023

5. Lee SJ, Kim EK, Kim YS, Hwang JW, Lee KH, Choi DK, et al. Purification and characterization of a nitric oxide inhibitory peptide from Ruditapes philippinarum. Food Chem Toxicol. 2012;50(5):1660-6.

https://doi.org/10.1016/j.fct.2012.02.021

6. Lee SJ, Cheong SH, Kim YS, Hwang JW, Kwon HJ, Kang SH, et al. Antioxidant activity of a novel synthetic hexa-peptide derived from an enzymatic hydrolysate of duck skin by-products. Food Chem Toxicol. 2013;62:276-80.

https://doi.org/10.1016/j.fct.2013.08.054

7. Chakrabarti S, Jahandideh F, Wu J. Food-derived bioactive peptides on inflammation and oxidative stress. Biomed Res Int. 2014;2014:Article ID 608979.

https://doi.org/10.1155/2014/608979
8. Cian RE, López-Posadas R, Drago SR, de Medina FS, Martínez-Augustin O. A Porphyra columbina hydrolysate upregulates IL-10 production in rat macrophages and lymphocytes through an NF-KB, and p38 and JNK dependent mechanism. Food Chem. 2012;134(4):1982-90.

https://doi.org/10.1016/j.foodchem.2012.03.134

9. Fosgerau K, Hoffmann T. Peptide therapeutics: Current status and future directions. Drug Discov Today. 2015;20(1): 122-8.

https://doi.org/10.1016/j.drudis.2014.10.003

10. Hartmann R, Meisel H. Food-derived peptides with biological activity: From research to food applications. Curr Opin Biotechnol. 2007;18(2):163-9.

https://doi.org/10.1016/j.copbio.2007.01.013

11. VoTS, Ryu B, Kim SK. Purification of novel anti-inflammatory peptides from enzymatic hydrolysate of the edible microalgal Spirulina maxima. J Funct Foods. 2013;5(3):1336-46.

https://doi.org/10.1016/j.jff.2013.05.001

12. Chi CF, Hu FY, Wang B, Li T, Ding GF. Antioxidant and anticancer peptides from the protein hydrolysate of blood clam (Tegillarca granosa) muscle. J Funct Foods. 2015;15:301-13. https://doi.org/10.1016/j.jff.2015.03.045

13. Mine Y, Ma F, Lauriau S. Antimicrobial peptides released by enzymatic hydrolysis of hen egg white lysozyme. J Agric Food Chem. 2004;52(5):1088-94.

https://doi.org/10.1021/jf0345752

14. Nagaoka S, Shimizu K, Kaneko H, Shibayama F, Morikawa K, Kanamaru Y, et al. A novel protein C-phycocyanin plays a crucial role in the hypocholesterolemic action of Spirulina platensis concentrate in rats. J Nutr. 2005;135(10):2425-30. https://doi.org/10.1093/jn/135.10.2425

15. Hong F, Ming L, Yi S, Zhanxia L, Yongquan W, Chi L. The antihypertensive effect of peptides: A novel alternative to drugs? Peptides. 2008;29(6):1062-71.

https://doi.org/10.1016/j.peptides.2008.02.005

16. Mukhopadhya A, Noronha N, Bahar B, Ryan MT, Murray BA, Kelly PM, et al. Anti-inflammatory effects of a casein hydrolysate and its peptide-enriched fractions on TNF $\alpha$-challenged Caco-2 cells and LPS-challenged porcine colonic explants. Food Sci Nutr. 2014;2(6):712-23.

https://doi.org/10.1002/fsn3.153

17. Tiwary E, Gupta R. Rapid conversion of chicken feather to feather meal using dimeric keratinase from Bacillus licheniformis ER-15. J Bioprocess Biotech. 2012;2(4):Article no. 1000123.

https://doi.org/10.4172/2155-9821.1000123

18. AOAC Official Method 994.12. Amino acids in feeds. Rockville, MD, USA: AOAC International; 2011.

19. Bradford MM. A rapid and sensitive method for the quantitation of microgram quantities of protein utilizing the principle of protein-dye binding. Anal Biochem. 1976;72(1-2): 248-54.

https://doi.org/10.1016/0003-2697(76)90527-3 
20. Chantaranothai C, Palaga T, Karnchanatat A, Sangvanich P. Inhibition of nitric oxide production in the macrophage-like RAW 264.7 cell line by protein from the rhizomes of Zingiberaceae plants. Prep Biochem Biotechnol. 2013;43(1):60-78. https://doi.org/10.1080/10826068.2012.697958

21. Ren J, Zhao M, Shi J, Wang J, Jiang Y, Cui C, et al. Purification and identification of antioxidant peptides from grass carp muscle hydrolysates by consecutive chromatography and electrospray ionization-mass spectrometry. Food Chem. 2008;108(2):727-36. https://doi.org/10.1016/j.foodchem.2007.11.010

22. Saisavoey T, Sangtanoo P, Reamtong O, Karnchanatat A. Antioxidant and anti-inflammatory effects of defatted rice bran (Oryza sativa L.) protein hydrolysates on RAW 264.7 macrophage cells. J Food Biochem. 2016;40(6):731-40. https://doi.org/10.1111/jfbc.12266

23. Cooper B. Doubling down on phosphorylation as a variable peptide modification. Proteomics. 2016;16(18):2444-7. https://doi.org/10.1002/pmic.201500440

24. Drummond e Silva FG, Hernández-Ledesma B, Amigo L, Netto FM, Miralles B. Identification of peptides released from flaxseed (Linum usitatissimum) protein by Alcalase ${ }^{\circledR}$ hydrolysis: Antioxidant activity. LWT - Food Sci Technol. 2017;76(Part A):140-6. https://doi.org/10.1016/j.lwt.2016.10.049

25. Livak KJ, Schmittgen TD. Analysis of relative gene expression data using real-time quantitative PCR and the $2^{-\triangle \Delta C T}$ method. Methods. 2001;25(4):402-8.

https://doi.org/10.1006/meth.2001.1262

26. Wu Y, Shu J, He C, Li M, Wang Y, Ou W, He Y. ROCK inhibitor Y27632 promotes proliferation and diminishes apoptosis of marmoset induced pluripotent stem cells by suppressing expression and activity of caspase 3. Theriogenology. 2016; 85(2):302-14.

https://doi.org/10.1016/j.theriogenology.2015.09.020

27. Kim EK, Kim YS, Hwang JW, Kang SH, Choi DK, Lee KH, et al. Purification of a novel nitric oxide inhibitory peptide derived from enzymatic hydrolysates of Mytilus coruscus. Fish Shellfish Immunol. 2013;34(6):1416-20.

https://doi.org/10.1016/j.fsi.2013.02.023

28. Hasegawa S, Ichiyama T, Sonaka I, Ohsaki A, Okada S, Wakiguchi $\mathrm{H}$, et al. Cysteine, histidine and glycine exhibit anti-inflammatory effects in human coronary arterial endothelial cells. Clin Exp Immunol. 2012;167(2):269-74.

https://doi.org/10.1111/j.1365-2249.2011.04519.x

29. Tsune I, Ikejima K, Hirose M, Yoshikawa M, Enomoto N, Takei $\mathrm{Y}$, Sato N. Dietary glycine prevents chemical-induced experimental colitis in the rat. Gastroenterology. 2003;125(3): 775-85.

https://doi.org/10.1016/S0016-5085(03)01067-9

30. Kim SK, Kim YT, Byun HG, Nam KS, Joo DS, Shahidi F. Isolation and characterization of antioxidative peptides from gelatin hydrolysate of Alaska pollack skin. J Agric Food Chem. 2001;49(4):1984-9.

https://doi.org/10.1021/jf000494j

31. Li XX, Han LJ, Chen LJ. In vitro antioxidant activity of protein hydrolysates prepared from corn gluten meal. J Sci Food Agric. 2008;88(9):1660-6.

https://doi.org/10.1002/jsfa.3264

32. Nalinanon S, Benjakul S, Visessanguan W, Kishimura H. Improvement of gelatin extraction from bigeye snapper skin using pepsin-aided process in combination with protease inhibitor. Food Hydrocoll. 2008;2(4)2:615-22.

https://doi.org/10.1016/j.foodhyd.2007.01.012

33. Wang AY, Zhou MY, Lin WC. Antioxidative and anti-inflammatory properties of Citrus sulcata extracts. Food Chem. 2011;124( 3):958-63.

https://doi.org/10.1016/j.foodchem.2010.07.035

34. Ahn CB, Je JY, Cho YS. 2012. Antioxidant and anti-inflammatory peptide fraction from salmon byproduct protein hydrolysates by peptic hydrolysis. Food Res Int. 2011;49(1):92-8. https://doi.org/10.1016/j.foodres.2012.08.002

35. Lee M, Kovacs-Nolan J, Archbold T, Fan MZ, Juneja LR, Okubo T, Mine Y. Therapeutic potential of hen egg white peptides for the treatment of intestinal inflammation. J Funct Foods. 2009;1(2):161-9.

https://doi.org/10.1016/j.jff.2009.01.005

36. Hwang JW, Lee SJ, Kim YS, Kim EK, Ahn CB, Jeon YJ, et al. Purification and characterization of a novel peptide with inhibitory effects on colitis induced mice by dextran sulfate sodium from enzymatic hydrolysates of Crassostrea gigas. Fish Shellfish Immunol. 2012;33(4):993-9.

https://doi.org/10.1016/j.fsi.2012.08.017

37. Kovacs-Nolan J, Zhang H, Ibuki M, Nakamori T, Yoshiura K, Turner PV, et al. The PepT1-transportable soy tripeptide VPY reduces intestinal inflammation. Biochim Biophys Acta Gen Subj. 2012;1820(11):1753-63.

https://doi.org/10.1016/j.bbagen.2012.07.007

38. Hsu KC, Li-Chan ECY, Jao CL. Antiproliferative activity of peptides prepared from enzymatic hydrolysates of tuna dark muscle on human breast cancer cell line MCF-7. Food Chem. 2011;126(2):617-22.

https://doi.org/10.1016/j.foodchem.2010.11.066

39. Bougatef A, Nedjar-Arroume N, Manni L, Ravallec R, Barkia A, Guillochon D, Nasri M. Purification and identification of novel antioxidant peptides from enzymatic hydrolysates of sardinelle (Sardinella aurita) by-products proteins. Food Chem. 2010;118(3):559-65.

https://doi.org/10.1016/j.foodchem.2009.05.021

40. Jang A, Jo C, Kang KS, Lee M. Antimicrobial and human cancer cell cytotoxic effect of synthetic angiotensin-converting enzyme (ACE) inhibitory peptides. Food Chem. 2008;107(1):327-36.

https://doi.org/10.1016/j.foodchem.2007.08.036 
41. Del Carmen Millán-Linares M, Bermúdez B, del Mar Yust M, Millán F, Pedroche J. Anti-inflammatory activity of lupine (Lupinus angustifolius L.) protein hydrolysates in THP-1-derived macrophages. J Funct Foods. 2014;8:224-33. https://doi.org/10.1016/j.jff.2014.03.020

42. Wang SY, Lan XY, Xiao JH, Yang JC, Kao YT, Chang ST. Antiinflammatory activity of Lindera erythrocarpa fruits. Phytother Res. 2008;22(2):213-6.

https://doi.org/10.1002/ptr.2289

43. Brown CM, Dela Cruz CD, Yang E, Wise PM. Inducible nitric oxide synthase and estradiol exhibit complementary neuroprotective roles after ischemic brain injury. Exp Neurol. 2008;210(2):782-7.

https://doi.org/10.1016/j.expneurol.2007.11.021

44. Park EM, Cho S, Frys KA, Glickstein SB, Zhou P, Anrather J, et al. Inducible nitric oxide synthase contributes to gender differences in ischemic brain injury. J Cereb Blood Flow Metab. 2006;26(3):392-401.

https://doi.org/10.1038/sj.jcbfm.9600194

45. Rahman I, Adcock IM. Oxidative stress and redox regulation of lung inflammation in COPD. Eur Respir J. 2006;28: 219-42.

https://doi.org/10.1183/09031936.06.00053805

46. Hwang JS, Yoo HJ, Song HJ, Kim KK, Chun YJ, Matsui T, Kim HB. Inflammation-related signaling pathways implicating TGF $\beta$ are revealed in the expression profiling of MCF7 cell treated with fermented soybean, chungkookjang. Nutr Cancer. 2011;63(4):645-52.

https://doi.org/10.1080/01635581.2011.551987

47. Nielsen DSG, Theil PK, Larsen LB, Purup S. Effect of milk hydrolysates on inflammation markers and drug-induced transcriptional alterations in cell-based models. J Anim Sci. 2012;90(Suppl 4):403-5.

https://doi.org/10.2527/jas.53953

48. Vernaza MG, Dia VP, de Mejia Gonzalez E, Chang YK. Antioxidant and antiinflammatory properties of germinated and hydrolysed Brazilian soybean flours. Food Chem. 2012;134(4):2217-25.

https://doi.org/10.1016/j.foodchem.2012.04.037

49. Majumder K, Chakrabarti S, Davidge ST, Wu J. Structure and activity study of egg protein ovotransferrin derived peptides (IRW and IQW) on endothelial inflammatory response and oxidative stress. J Agric Food Chem. 2013; 61(9):2120-9.

https://doi.org/10.1021/jf3046076

50. Iskandar MM, Dauletbaev N, Kubow S, Mawji N, Lands LC. Whey protein hydrolysates decrease IL-8 secretion in lipopolysaccharide (LPS)-stimulated respiratory epithelial cells by affecting LPS binding to Toll-like receptor 4 . Br J Nutr. 2013;110(1):58-68.

https://doi.org/10.1017/S0007114512004655 